\title{
Magnitude and frequency of debris and slush flows in the Khibiny mountain valleys, Kola Peninsula, NW Russia
}

\author{
Ekaterina V. Garankina ${ }^{1}$, Vladimir R. Belyaev ${ }^{2}$, Fedor A. Romanenko ${ }^{1}$, Maxim M. Ivanov ${ }^{2}$, \\ Natalia V. Kuzmenkova ${ }^{3}$, Artem L. Gurinov ${ }^{1}$, and Egor D. Tulyakov ${ }^{1}$ \\ ${ }^{1}$ Department of Geomorphology and Paleogeography, Faculty of Geography, \\ Lomonosov Moscow State University, Moscow, 119991, Russia \\ ${ }^{2}$ Laboratory for Soil Erosion and Fluvial Processes, Faculty of Geography, \\ Lomonosov Moscow State University, Moscow, 119991, Russia \\ ${ }^{3}$ Department of Radiochemistry, Faculty of Chemistry, Lomonosov Moscow State University, \\ Moscow, 119991, Russia \\ Correspondence: Ekaterina V. Garankina (evgarankina@gmail.com)
}

Published: 1 August 2019

\begin{abstract}
Available results for five studied valleys of the Khibiny Mountains, Kola Peninsula, suggest that slush flows and, possibly for some valleys, typical debris flows with lower frequency, are a leading mechanism for downstream sediment delivery and valley floor topographical formation. Typical fluvial topography in slush flow-affected basins is extremely suppressed or nonexistent, since under such conditions, stream channels are unable to rework slush flow deposits. The recovery phase of fluvial topography can serve as an indicator of the magnitude and time passed since the last extreme event. A combination of grain size analysis, radionuclide fingerprinting with the ${ }^{232} \mathrm{Th}$ content in the finer-grained sediment matrix (size $<10 \mathrm{~mm}$ ) and ${ }^{14} \mathrm{C}$ dating, were applied to reveal the age and common structure of debris and slush flow environments and to investigate the main factors in their lithodynamics. Those helped to estimate transportation distances and capacities of the flows and the amount of fluvial reworking of its deposits with time. Application of radiocarbon dating to determine absolute ages (about 30 dates) of stabilization periods for the colluvial cones, mountain fans and valley bottoms and integration with other available chronological data provided a basis for distinguishing several stages of decreased activity of debris and slush flows and extreme slope failures through the second half of the Holocene. Field mapping and remote sensing data interpretation revealed spatial distribution patterns of debris and slush flows. Geomorphic analysis of large relic landforms in valley bottoms confirms, in general, the case for a significant reduction of debris flow magnitude since the last deglaciation and distinct shift to slush flow processes with much lower clastic content. A reliable chronology of the early events is yet to be obtained representing a challenging problem for future research.
\end{abstract}

\section{Introduction}

The largest mountain massif of the Kola Peninsula - Khibiny - is comprised of Devonian alkaline intrusions (Pozhilenko et al., 2002). Compact plateau-shaped mountains (up to 1201 ma.s.l.), with relatively steep slopes, are dissected by numerous deep (100-400 m) erosional valleys, glacial troughs and cirques, and tectonic lineaments. Extremely rich in minerals, especially in apatite and nepheline ores and rare earth elements (Fig. 1), Khibiny have been intensely explored since the 1920s. Recently, the area has become a focus of a rapidly growing recreational industry. At the same time as being an arena of widespread natural hazards, its industrial and civil infrastructure (ski resorts, newly established $\mathrm{Na}$ tional park, quarries, mines, plants, roads, etc.) is strongly affected by snow avalanches, rockfalls, screes, and debris flows (Belyaev et al., 2015). The most frequently observed types of the latter are snowmelt period slush flows and rainfallinduced medium magnitude debris flows (Perov et al., 2017). 
Slush flow represents a specific gravitational flow of a watersaturated mixture of snow and a limited amount of clastic sediment (up to $12 \%$, clasts size up to $1-2 \mathrm{~m}$ ) occurring in low-order stream channels (Perov, 1996; Bozhinsky and Myagkov, 2001; Fleishman, 1978). Slush flows are classified as subtypes of wet snow avalanches or debris flows or as independent phenomena between the latter two (Hestnes, 1998; Eckerstorfer and Christiansen, 2012).

Resembling sets of hazardous episodes, some with fatal consequences, are reported for other mountainous Arctic and Subarctic environments in Russia, Scandinavia (Nyberg, 1989; Hestnes and Kristensen, 2010; Jonsson and Gauer, 2014) and Northern America (André, 1995; Larocque et al., 2001; Relf et al., 2015, etc.). In Japan, more than 90 casualties due to slush flows have been registered since 1945 (Kobayashi et al., 1994). To estimate potential risks of these hazards, a thorough understanding of their nature and dynamics is required.

The Khibiny Mountains provide a unique dataset of more than 200 catchments affected by slush flows for the last centennial (Bozhinsky and Myagkov, 2001). Fifty years of survey mainly concentrated on monitoring the observed events and developing protection recommendations for mining infrastructure (Chernous, 2006) whilst the distribution, magnitude and frequency of such hazardous events in the past remained beyond the scope of exploration. However, largescale bottom and piedmont fans found in the majority of small valleys do not always correspond to a glacial origin suggesting previous periods of much higher debris flow intensity. Given the lack of spatial data and absolute age determinations, improved understanding of correlations between such deposits and landforms is essential for reliable paleogeographic reconstructions. In this article, we therefore try to evaluate dynamics of debris and slush flows during the Holocene in the Khibiny mountain valleys.

\section{Methods}

Comprehensive field investigations including detailed descriptions of several geological sections were accomplished in five valleys of the Kuna River, Malaya Belaya River, and Bolshaya Belaya River basins (Fig. 1). Geomorphic interpretation of high-resolution satellite imagery from public services, aerial photography both archived and obtained by UAV DJI Phantom III, and 1:50000 scale topographic maps assembled evidence for relic and active debris flows. The relative ages of these phenomena were estimated based on both morphological indications and vegetative cover (Rudinskaya et al., 2018).

Grain size analysis, radionuclide fingerprinting, and ${ }^{14} \mathrm{C}$ dating were applied to reveal the age and common structure of the debris flow environments, and the main factors affecting their lithodynamics. Fresh slush flow accumulations were sampled for assessment of deposition and fluvial re- working rates. Surface sampling of channel beds and banks, valley bottoms and sides helped to specify the modern patterns and agents of basin-scale sediment redistribution based on ${ }^{232} \mathrm{Th}$ content. Cross-sections of superimposed debris and slush flow, fluvial and colluvial, lacustrine and peat deposits in terraces and fans between 1 and $10 \mathrm{~m}$ above the streams were sampled to establish both distinctive features of each genetic type and their age.

We applied a standard procedure for the finer-grained sediment matrix (size $<10 \mathrm{~mm}$ ) dry sieving with the Fritsch Analysette 3 PRO shaker to separate fractions of $<0.05$, $0.05-0.1,0.1-0.25,0.25-0.5,0.5-1,1-2,2-5$, and $5-10 \mathrm{~mm}$. For gamma-spectrometric analysis, each fraction was ground and weighed into $1 \mathrm{~g}$ subsamples. Gamma activities of ${ }^{232} \mathrm{Th}$ daughter radionuclides ${ }^{212} \mathrm{~Pb}$ and ${ }^{228} \mathrm{Ac}$ were measured with the ORTEC GEM-C5060P4-B HPGe detector. Alpha activities of ${ }^{228,232} \mathrm{Th}$ isotopes of sequentially extracted aliquots of the most active samples were measured with the ORTEC Alpha-Ensemble-2 with detector ENS-U900 type UL-TRAAS displaying the content and ratio of ${ }^{212} \mathrm{~Pb}$ and ${ }^{228} \mathrm{Ac}$ and corresponding physicochemical forms of ${ }^{232} \mathrm{Th}$ (Ivanov et al., 2019).

A limited geochronological framework was established by ${ }^{14} \mathrm{C}$ dating of buried humic and peat layers between superimposed debris flow deposits. The results were compared to the published Holocene chronology of local slope processes. Scintillation radiocarbon dating was performed at the Laboratory of Radiocarbon Dating and Electron Microscopy, IG RAS, Russia.

\section{Results}

In 2015, we started investigations of the frequency and age of debris and slush flow events in the Khibiny (Garankina et al., 2018) and Lovozerskiye Tundry (Rudinskaya et al., 2018). Field observations revealed both modern and older corresponding landforms: valley floor and stream bank incisions, ridges, lobes and hummocks, debris covers, terraces, and fans. The surfaces of relatively fresh landforms have no or poor vegetation cover (fragmentary mosses, lichens, herbs, shrubs) and do not exceed 1 to $2 \mathrm{~m}$ in height and $0.02 \mathrm{~km}^{2}$ in area. Older features are larger (up to $10 \mathrm{~m}$ high and 0.05$0.4 \mathrm{~km}^{2}$ in area) and are mostly well forested or covered by thick tundra. Deposits vary from large boulders and blocks to sandy silts depending on the geomorphic position above the streambed, the distance from the sources, age, and flow energy. Usually, up to three levels of debris or slush flow accumulations of different age can be distinguished. Along the middle reaches of $2 \mathrm{nd}$ and $3 \mathrm{rd}$ order streams, they are traced as sequences of inclined terraces. In the lower reaches, they appear as a series of humic or peat layers buried between coarse deposits in slush flow fans.

Most fresh slush flow deposits were found days to months after their accumulation in valleys of the Alyavumjok, North- 


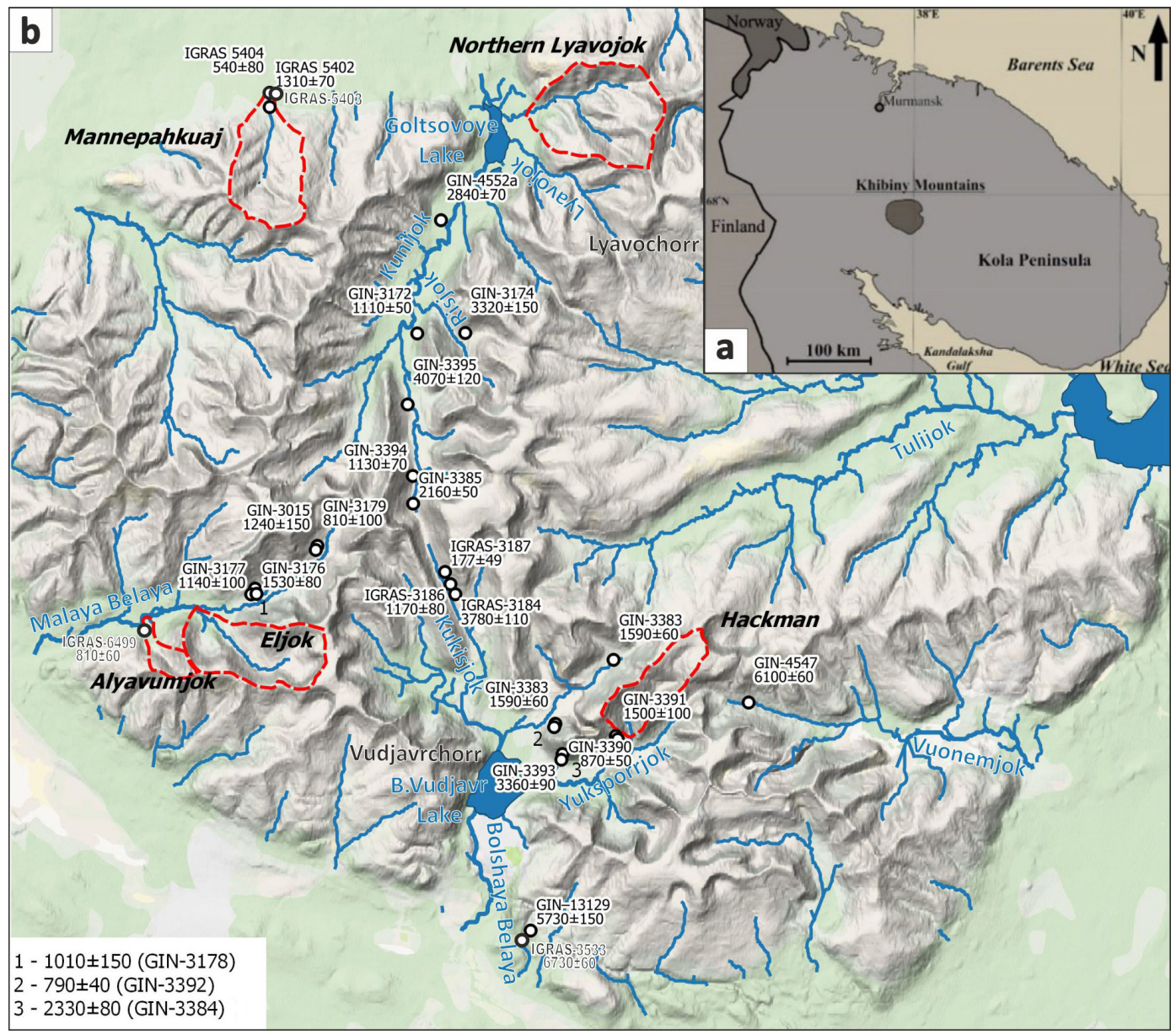

Figure 1. Location of the Khibiny Mountains on the Kola Peninsula, NW Russia (a) and case study basins (b) (source: (C) Google global topography, infrastructure and settlements). Panel (b) shows the distribution of a dataset of ${ }^{14} \mathrm{C}$ dates of buried organic-rich horizons in colluvial and debris flow fans (after Sulerzhitskiy et al., 1986; Vashchalova, 1987; Bozhinsky and Myagkov, 2001; Vladychensky et al., 2007; Kosareva, 2007; Romanenko et al., 2011, with alterations).

ern Lyavojok, and Mannepahkuaj rivers. In the latter, they formed thin debris covers, individual hummocks up to $1.5 \mathrm{~m}$ high and ridges 7-8 $\mathrm{m}$ long during the 2016 early spring snowmelt (fresh silty gravel and boulder loads at the confluence of main headwaters were registered at the end of June). Analysis of freely available remote sensing data allowed determination of the associated slush flow discharge periods in the spring of 2014 and at least once before, in 2012-2013. A slush flow from the main Northern Lyavojok tributary constituted a larger debris fan protruding into the forested valley bottom. Based on the sparse vegetative cover, this slush flow occurred less than 10-15 years ago.

At the footslope of the Vudjavrchorr Mountain, Southern Khibiny, a deep V-shaped erosional incision cuts into the $150 \mathrm{~m}$ thick glacial drifts. Here, the fan has several prominent age generations represented by a series of inclined lobes with $\sim 2 \mathrm{~m}$ difference in elevation between each other (Fig. 2). Their surfaces are armored by sand and gravel with some boulders with small clastic ridges atop. The lobe nearest to the channel is devoid of vegetation, while the most remote one is already covered by dwarf willows and birches. This can be considered as evidence of repeated slush flow activity over the last centuries. The youngest non-vegetated fan surface is morphologically fresh and is observed on 1958 airborne photos. It can be speculated that it was formed over the last 100 years (Table 1). In close vicinity, there is another similar erosional cut but under the dense spruce forest, suggesting it is of earlier origin. Corresponding older fan is also completely vegetated and consists of deposits of two ages.

Evidence of relatively young slush flows of substantial volume is observed in the Malaya Belaya River basin. Two small catchments (Alyavumjok and Eljok) on its left side have large unvegetated fans. The valley floor of the former is almost devoid of loose deposits, and the latter has a deep (up to $35 \mathrm{~m}$ ) V-shaped incision in the middle reaches. Debris fans $200-250 \mathrm{~m}$ in radius with boulder paving are shown on the first topographic maps from the 1930s. Thus, they are at least 90 years old, being superimposed on forested and even more 


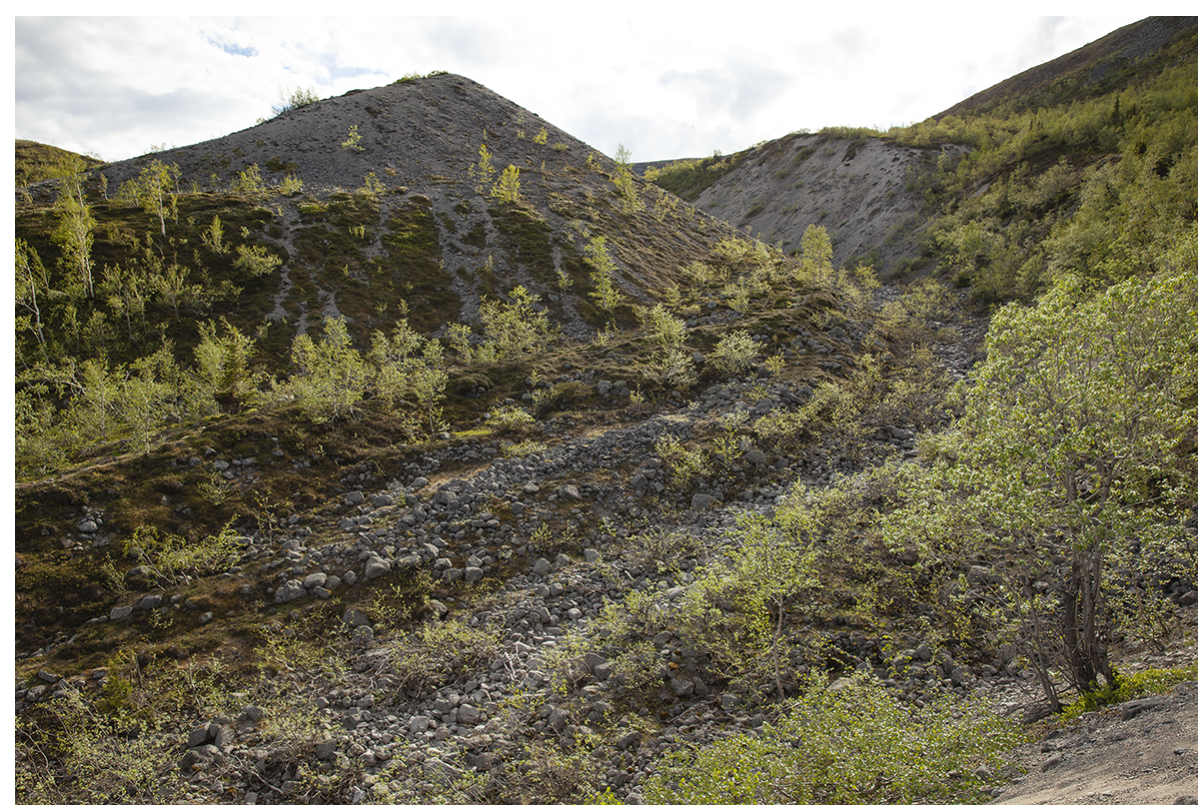

Figure 2. Several generations of debris flow fans distinguished by relative elevation and vegetation succession stages below the V-shaped cut into moraine under the southern slope of the Vudjavrchorr Mountain.

Table 1. Vegetation characteristics for indicating the age of debris or slush flow deposit, established for the forest belt in the Khibiny Mountains (after Bozhinsky and Myagkov, 2001).

\begin{tabular}{ll}
\hline Age, years ago & Landscape characteristic \\
\hline$<10$ & $\begin{array}{l}\text { Sparse grasses and dwarf shrubs } \\
\text { Dense grasses and dwarf shrubs with some } \\
10-20\end{array}$ \\
$\begin{array}{l}\text { young tree shoots } \\
20-50\end{array}$ & $\begin{array}{l}\text { Dominance of crooked birch forest } \\
50-100\end{array}$ \\
$>100$ & Mixed forest dominated by deciduous trees \\
\hline
\end{tabular}

expansive older fans, which displays repetitive activity of extreme slush flows. The older Alyavumjok fan overlapped the Malaya Belaya trough floor and forced the main river channel to shift its position significantly and, thus, a meander up to $350 \mathrm{~m}$ in radius to form. The frequency of such disastrous events can be estimated by ${ }^{14} \mathrm{C}$ dating of buried soils within the forested piedmont areas. A well-developed humic horizon under the post-slush flow flood sediment shows that the last extreme episode affected this part of the Alyavumjok fan less than 800 years ago (Fig. 5a) - subsequent to the occurrence of the above-mentioned meander.

The distribution of slush flow patterns and landforms is strongly controlled by tectonic structure. For example, the feather-shaped drainage network of the Mannepahkuaj Basin induces tributary slush flow runout zones in the main valley bottom. Such coarse debris dams occasionally block the main channel forcing the stream to filtrate through and leading to further outbursts. Downstream, such "wavy" structure of deposition repeatedly induced normal debris flows with unequal transportation distances of the sediment load. This caused a series of debris fan lobes of different sizes to form at the forested piedmont (up to $6 \mathrm{~km}$ from the sources). Ages of embryonic paleosols (Fig. 5a) in two successive deposition zones, $0.5 \mathrm{~km}$ apart, reflect high-magnitude debris flows at least twice per millennia and probably much more often (Garankina et al., 2018).

It has been determined that slush flow fans or other landforms in their deposition zones under certain conditions become an important control of the evolution of fluvial topography. In the higher order river basins, it is often challenging to recognize zones of dominant slush flow origin, transport or deposition. Smaller and less complex catchments (mostly of the 1st order streams) present distinctly confined slush flow morphodynamic zones. For more detailed investigations of the slush flow-fluvial interactions, several basins were chosen for grain size and radionuclide content evaluation.

In fresh slush flow and alluvial deposits at the Mannepahkuaj streambed (Fig. 3), sandy and silty fractions gradually increase downstream. In the lower reaches, inhomogeneity is caused by a combination of variable transportation capacities of different magnitude debris and slush flows and the amount of fluvial reworking of their deposits. Older fans and terraces in the middle reaches show much coarser composition, probably, due to the higher transportation capacity of slush flows in the past. This is in agreement with the much larger extent of correlated landforms (up to $10 \mathrm{~m}$ relative height). At the relic piedmont fan, the sand content increases, however, the grain size composition is generally finer than in modern slush flow deposits. This may be explained by the 

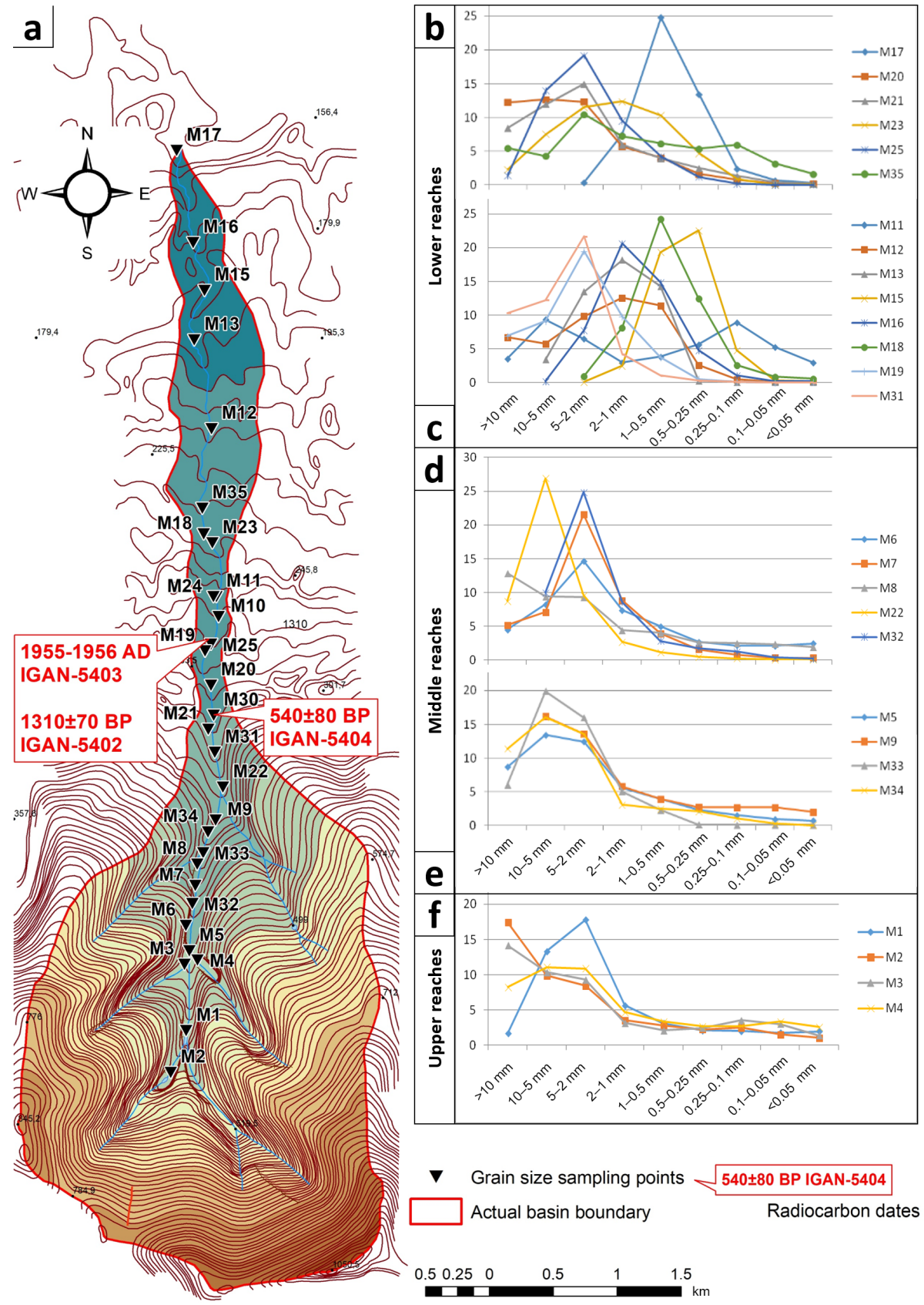

Figure 3. Grain size data of slush flow deposits in the Mannepahkuaj Basin: (a) sampling points on the elevation map. Distribution of granulometric fractions in samples from relic valley bottom features $(\mathbf{b}, \mathbf{d})$ and fresh accumulations in the river channel $(\mathbf{c}, \mathbf{e}, \mathbf{f})$.

greater area of the relic fan (approximately $8 \mathrm{~km}^{2}$, equivalent to the entire mountainous area of the basin) compared with the narrow strip of modern accumulation along the channel. Thus, stream bifurcation and rapid reduction in transportation capacity with distance from the mountains is likely to have occurred in the past. Hence, the main tendencies in longitudinal differentiation are gradual channelization of slush flow deposition, leaving large relic landforms inactive and the resultant shift in clastic material sorting, which substantially decreases with time.

Recent publications report the use of ${ }^{232} \mathrm{Th}$ radionuclides as tracers for distinguishing the main exogenous processes of sediment transport in the Khibiny valleys. For the Hackman basin with a strong ${ }^{232} \mathrm{Th}$ signal caused by radioactive mine tailings, gamma spectrometry analysis revealed definite ${ }^{232} \mathrm{Th}$ concentrations in valley bottom deposits in comparison with adjacent colluvial slopes and channel bed alluvium. 
This provides a basis for confirming episodic powerful removal and mixing of material along the valley by slush flows (Ivanov et al., 2018). The contribution of constant water flow within the stream channel is limited to washing the fine fractions out. The latter, according to the alpha spectrometry (Ivanov et al., 2019), make the most relevant contribution to the total radioactivity of the samples and can cause positive radioactive anomalies in sedimentation basins (deltas, lakes, artificial ponds) outside the catchments. Thus, secondary redeposition of the ${ }^{232} \mathrm{Th}$-rich fine fractions is possible downstream, along the receiving Yuksporrjok River and towards the Bolshoj Vudjavr Lake.

The Northern Lyavojok Valley - with confirmed but scattered ${ }^{232} \mathrm{Th}$ bedrock sources - was chosen for fingerprinting due to its potential for tracking the transport of radioactive sediment down to the Goltsovoye Lake with the frequent influence of slush flows in the background. The last (late Weichselian) continental ice cover left the Khibiny northern valleys almost devoid of glacial drifts; however, widespread thick debris fans, ridges, and elevated fragments of former valley floors prove high depositional intensity here in the past, interrupted by several major incisions, probably due to the subsidence of the local base level during deglaciation and continuing tectonic uplift (Garankina et al., 2018). In addition to the surface sampling of the valley, a bottom core obtained from the northern nearshore part of the Goltsovoye Lake containing a sediment record of at least the last $7 \mathrm{kyr}$ was examined for radionuclide content. Elevated

${ }^{232} \mathrm{Th}$ values in the lacustrine sediments are believed to identify periods of intensified delivery of ${ }^{232} \mathrm{Th}$-rich alluvium from the valley. Granulometric differentiation of sediments along the transportation path probably also takes place and can influence radioisotope concentrations (Fig. 4a). Gammaspectrometry measurements of unsupported ${ }^{210} \mathrm{~Pb}\left({ }^{210} \mathrm{~Pb}_{\mathrm{ex}}\right)$ concentration produced a complex depth distribution curve designating variable input of the radionuclides into the lacustrine environment. This depth profile revealed that the upper $0.3 \mathrm{~m}$ of sediments accumulated in the lake during the last 200 years (Fig. 4b). The high variability of ${ }^{232}$ Th activity detected in the lacustrine deposits may well be explained by periodic increased input of sediment into the lake caused by slush flows or extreme floods in the main eastern tributaries - Lyavojok and Northern Lyavojok.

\section{Discussion}

Magnitude and frequency analysis and dating of key activity periods for slope processes (screes, rockfalls), snow avalanches, debris and slush flows represent important areas of research for improving understanding of morphodynamics in the Khibiny. Work has already been undertaken to date phases of decreased activity of catastrophic processes (Perov, 1971; Vashchalova, 1987; Bozhinsky and Myagkov, 2001; Vladychensky et al., 2007; Kosareva, 2007; Roma- nenko et al., 2011; Nikolaeva, 2014; Shilova and Romanenko, 2016; Nikolaeva et al., 2016). These studies employed dendrochronology, airborne photograph interpretation, and landform analysis. Unfortunately, all these approaches are limited in terms of both temporal resolution and maximum possible dated age.

Sets of geobotanic landscape indicators for slush flow fan and colluvial (rockfall or scree) cone ages were distinguished (Table 1). In general, the longer the interval without catastrophic geomorphologic events, the denser the vegetation cover on a fan. However, it must be borne in mind that such indicators are inapplicable for the tundra landscapes occupying a large part of the mountain slopes and summits with slush flow-affected catchments.

Perov $(1966,1971)$ first used a dendrochronological approach in the Kunijok River basin, and this was later improved by Olga I. Budarina and Galina G. Sapunova (Bozhinsky and Myagkov, 2001). This approach is seriously limited by dependency on local hydrothermal conditions, soil, and substrate, poorly readable tree rings, and dramatic loss of information with increasing age. The most reliable dates can be obtained by measuring young shoots from the bases of trees fallen or deformed by flows. On this basis, massive activations of slush flows were established for 1943, 1946, 1950-1952, 1960, 1966, 1969, 1977, and 1987 (Perov, 1966; Sapunov, 1991; Bozhinsky and Myagkov, 2001). Ananiev (1998) reported massive slush flow traces in the Hackman Valley that had almost damaged the infrastructure of the Rasvumchorr mines in May 1995.

Avalanches in the Kola Mountains typically occur annually - snow bodies are regularly found in valleys and can remain unthawed till the following winter. Rockfall, scree, and debris flow processes normally take place much less frequently. However, huge block fields - seismic rockfall bodies - are widespread on the foothills. In several basins of the Northern and Western Khibiny, dramatic imprints of extreme events represented by substantial clastic volume but which was transported for relatively short distances $(0.5-$ $2 \mathrm{~km})$ are regarded as traces of seismically triggered catastrophic events. Combinations of poorly sorted large clastic bodies (block sizes $>1-3 \mathrm{~m}$ ) occupying cirque and valley bottoms and thick debris fans blocking adjacent small tributary valleys or thrown into the main troughs provide evidence for simultaneous or consequent rockfalls and debris flows (Garankina and Lukashov, 2018). Previously, Romanenko et al. (2011) reported a bog dated about $5.7 \mathrm{ka}$ that was formed due to damming of the small valley by a debris flow fan in the southern Khibiny. A seismic event had most likely triggered a rockfall causing catastrophic water outburst from the lake in the headwaters. Slope mass movements, in contrast, cover most parts of the mountains, but result in much slower and yet distinct translocations of colluvial mantle and soils burial. Those features are revealed by mobile plant communities and the dynamics of cryogenic microtopography (Garankina, 2013). 


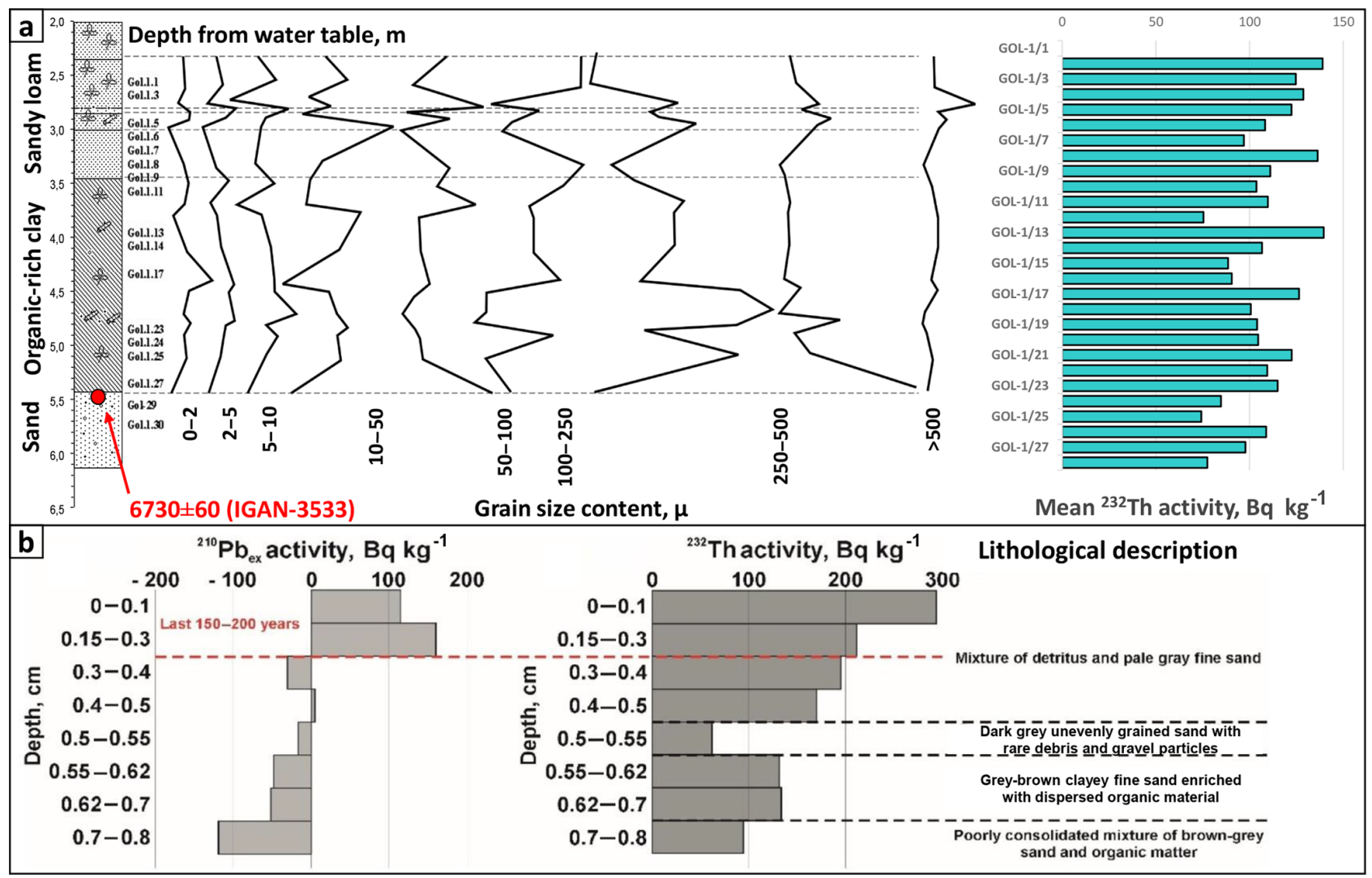

Figure 4. Redistribution of ${ }^{232} \mathrm{Th}$ radionuclides in lacustrine sediments of the Goltsovoye Lake (a). Depth distribution of ${ }^{210} \mathrm{~Pb}$ ex ${ }^{2}{ }^{232} \mathrm{Th}$ in the upper part of the profile (b).

The introduction of the radiocarbon method became a turning point in progressing understanding of the age of all of the above-mentioned processes. However, dating of the catastrophic events themselves is still rather difficult. Their age limits are most reliably obtained by testing organic compounds formed during periods of relative stability, which separate the phases of extreme activities. Such materials include peat and primitive soil layers or even lenses of mineral substrate with little content of humified matter. Such layers form on stable surfaces and later become buried by younger clastic deposits. For the events themselves, such dates determine lower (prior to the event) time marks or, alternatively, both lower (prior) and upper (post-event) marks in sections with several datable organic horizons separating several clastic layers.

Vashchalova (1987) assembled the first series of ${ }^{14} \mathrm{C}$ dates within the interval from 810 to $6100{ }^{14} \mathrm{C}$ years (Fig. 1) in the Khibiny Mountains and successfully determined periods of decreased snow avalanches, screes, and rockfalls dynamics. Combined with the dates acquired during this particular study (Fig. 5a) and previous research (Romanenko et al., 2011), a dataset of up to $30{ }^{14} \mathrm{C}$ dates was compiled (Fig. 5b). This dataset suggests that in the second half of the Holocene, the intensity of catastrophic slope and slush flow processes could have increased during the periods $\mathrm{BCE}$ 3600-2800, 1500-1250, 850-700, BCE 150-CE 300, and since CE 1350 years. The initiation of the potential latest activity seems to coincide with the beginning of the so-called Little Ice Age of the XIV-XIX centuries. In the case of the dynamics of snow avalanches, this pattern is explained by the better snow supply (Vashchalova, 1987). Intensification of slope processes and debris flows can also be proposed for the beginning of the Holocene climatic optimum between 7.5 and $6 \mathrm{ka}$ (BCE 5500-4000 years). However, there is a certain spatial inhomogeneity of stabilization periods to be found over the Khibiny area. For the historic times, definite episodes of intensification of catastrophic processes can be determined for individual basins not responding to the regional signal and potentially caused by varying local geomorphic and snow cover conditions.

The current insufficient number and spatial coverage of the available dates point to the need for collecting more data on debris flow phenomena over the entire Late Glacial-Early Holocene. Nevertheless, the extensive occurrence of distinctive large relic landforms and thick bottom deposits without any detectable organic matter indicates a substantially higher magnitude of debris flow activity in the distant past. Most likely, these debris flows functioned in colder and snowier 


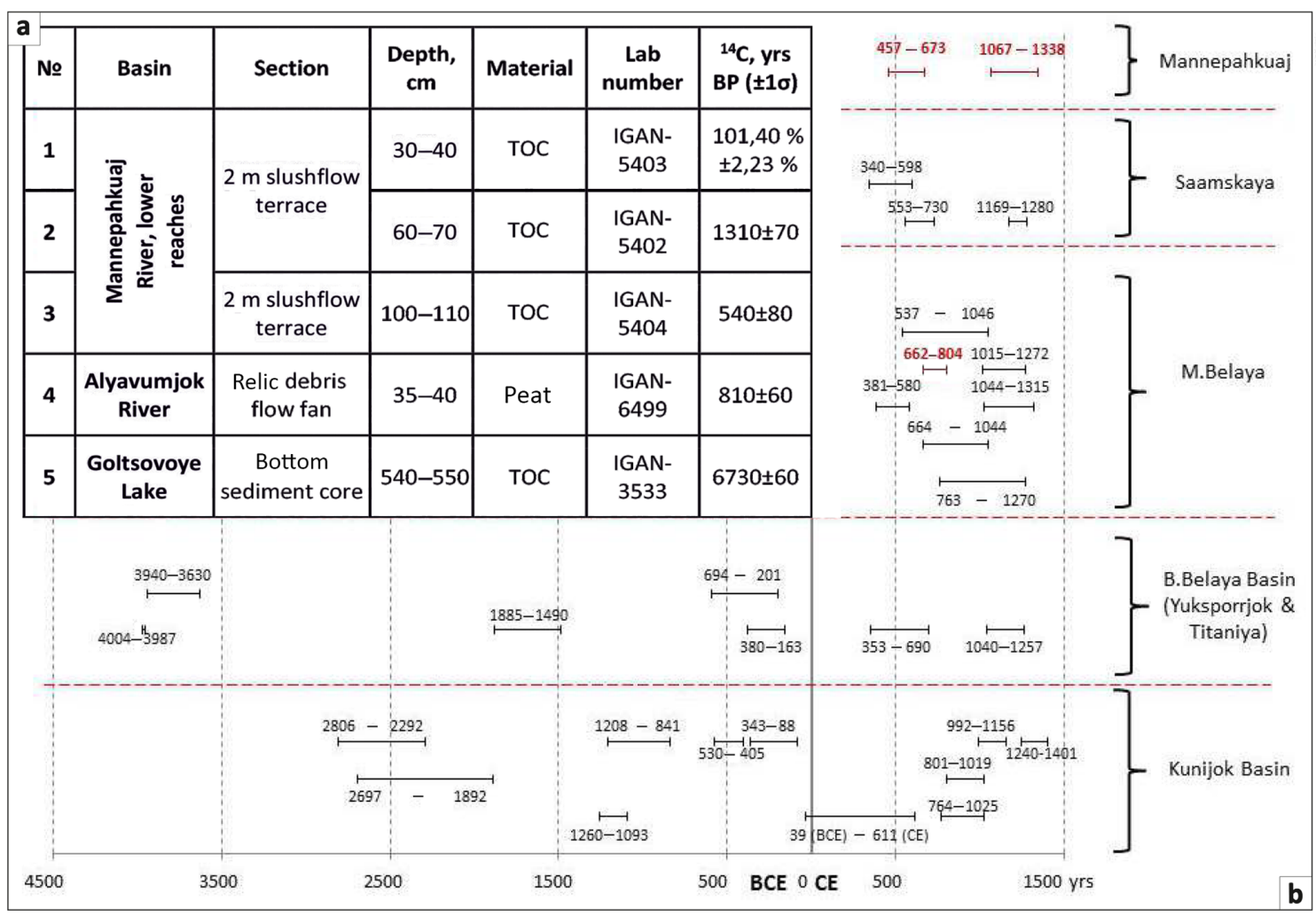

Figure 5. Holocene geochronology for the valleys in the Khibiny Mountains. New ${ }^{14} \mathrm{C}$ dating results (a). Intervals (calibrated ages) of buried soil horizons in debris flow fans and slope cones (b).

environments during the last deglaciation stages. Here, it is probable that the remaining mountain glaciation in the affected valley headwaters caused periodical moraine-dammed lake outbursts and associated glaciogenic debris flows.

Interpretation of the evidence can be substantially improved by comparing data from other natural paleoarchives reflecting the general tendencies of landscape evolution. Traces of catastrophic events fixed in lake bottom sediment records can be revealed by supplementary approaches. For instance, recent work by a research group from the Kola Scientific Center RAS (Nikolaeva et al., 2016) revealed a catastrophic outburst into the Imandra Lake from the surrounding mountainous catchments as indicated by a coarse clastic breccia-type layer within the gyttja deposits. The authors associate this outburst with the seismic event between 6.5 and $5.6{ }^{14} \mathrm{C}$ ka. Nikolaeva (2014) also attribute folding and faulting deformations in varved clays of the Vuonemjok valley to a seismic event dated to Allereod; however, opposing interpretation of such disturbed lacustrine lamination as a result of a glacial outburst flood or debris flow impact was also proposed by Gorbatov and Kolesnikov (2017).

A prominent $6 \mathrm{~cm}$ thick layer of clear grey silt was found within organic deposits southward of the Goltsovoye Lake. As reported by Shilova and Romanenko (2016), this layer is younger than $5.5 \mathrm{ka}$ and contains a substantially lower amount and taxonomic variability of diatoms, although without significant differentiation of their species. In addition, higher amounts of terrigenous material are characteristic for the underlying Early Holocene sandy facies. All of the above can be taken as evidence of some catastrophic (probably, debris flow) events within the basin, which caused fast and large-scale inputs of mineral sediment into the lake mainly at the beginning and occasionally in the second part of the Holocene.

The erosional potential of slush and debris flows can be estimated based on geomorphic footprints. Deep V-shaped incisions widespread in the upper reaches of the 1st order streams, which are almost dry during most of the warm season, attest to an origin resulting from an agent other than fluvial. In places, these features incise even bedrock, revealing the substantial intensities of the eroding flows. Normally, the catchment areas above them (cirques, niches, etc.) provide abundant snow and water supply and serve as modern slush flow sources. Downstream in the major valleys, several incisive cycles are imprinted in the bottom topography. Based on the relatively low discharge rates and no geomorphic indication of active erosion by fluvial processes, those features should also be associated with slush flow episodes, probably caused by climatic oscillations, or sometimes, local base level decrease. 
A trend of reduction in the magnitude of debris flow phenomena since the last deglaciation is observed. During the early stage of the Holocene widespread debris flow deposition was dominant, leaving large geomorphic footprints inconsistent with modern runoff conditions. Most likely the largest of those were caused by proglacial lake outbursts. Later, debris flow transportation capacity and frequency decreased markedly, probably due to the reduction of both water and sediment sources. As a result, debris flows were largely replaced by slush flows with much lower clastic content, which resulted in much smaller modern accumulations. However, the higher erosional potential of slush flows has been causing ongoing incision into relic glacial and debris flow landforms.

\section{Conclusions}

Available results for the Khibiny Mountains suggest slush flows and typical debris flows with lower frequency are both leading mechanisms and underestimated agents of downstream sediment delivery and valley floor topographical formation during the Holocene.

1. In the 1 st order streams, fluvial topography is extremely suppressed or nonexistent as stream channels are unable to rework slush flow deposits and are forced to adjust passively. In typical erosional valleys of the 2nd order, fluvial processes are also almost completely paralyzed by even minor deposition as a result of highfrequency slush flows. Here, streams are limited to reworking the finer fractions of slush flow fans, forming secondary alluvial features downstream. Small valleys of the 3rd and higher stream orders with glacial topography, are usually devoid of slush flows except for lowmagnitude events of the wet avalanche type in riverbeds. Only rare major slush flow ejections from tributaries producing large superimposed fans in the main valley floor can influence their fluvial cycles. Such rare catastrophic events can lead to major river channel shifts and deep fresh-looking incisions.

2. The recovery phase of normal fluvial topography can be used to indicate the magnitude and time of the last extreme slush flow events by assessing the amount of fluvial reworking of associated deposits, transportation distances and capacities using grain size and radionuclide analyses.

3. The recurrence interval of medium magnitude slush flows does not exceed 10-30 years, which is in agreement with previously published monitoring data. Low magnitude events are even more frequent (up to every 1-2 years) in headwaters and tributaries of certain valleys. The frequency of extreme events is much lower and can be estimated as at least twice per millennia, according to radiocarbon dating, and is probably even higher.

4. Application of the radiocarbon method to determine the ages of stabilization periods for the Khibiny Mountains fans and valley bottoms provided a basis for distinguishing stages of non-uniform activity of slush flow phenomena during the second half of the Holocene, most likely controlled by climatic oscillations and, at places, by the fluctuations of local base levels. The intensity of catastrophic slope and slush flow processes increased during BCE 3600-2800, 1500-1250, 850-700, BCE 150-CE 300, and since CE 1350, and an even higher frequency of associated events can be speculated for the first half of the Holocene climatic optimum (7.5-6 ka) though direct geochronological evidence for this is still scarce.

5. Large geomorphic footprints inconsistent with modern runoff conditions and lacking any buried visible organic matter, in general, attest to a leading role of debris flows in sediment transport during the late deglaciation and the Early Holocene associated with repetitive breaches of moraine-dammed lakes and subsequent powerful glaciogenic debris flows. Later, a distinct decrease of debris flow transportation capacity and frequency occurred due to the depletion of both water and sediment sources. Here, debris flows were largely substituted by slush flows with much lower clastic content, which explains the much smaller modern sediment accumulations. However, the higher erosional potential of those phenomena caused a direct incision of glacial and debris flow landforms marked by a series of widespread deep superimposed cuts in valley bottoms. A transition period from the dominance of typical debris flows to that of the slush flows is yet to be determined more precisely by means of absolute geochronology and this represents the most challenging problem for future research in the area.

Data availability. The majority of the data presented here are from an ongoing and yet incomplete project. All datasets will be made (and partially already is) available on completion of the project and the results will be published with a link probably hosted by Russian Foundation for Basic Research. Please contact Ekaterina V. Garankina for further information.

Author contributions. All co-authors took part in field working and sampling. MMI and NVK performed radionuclide content studies. EDT carried out grain size analysis. FAR summarized previously accomplished geochronological data. ALG, VRB, and EVG designed cartographic and artwork and the latter prepared the manuscript with contributions from all co-authors. 
Competing interests. The authors declare that they have no conflict of interest.

Special issue statement. This article is part of the special issue "Land use and climate change impacts on erosion and sediment transport". It is a result of the ICCE Symposium 2018 - Climate Change Impacts on Sediment Dynamics: Measurement, Modelling and Management, Moscow, Russia, 27-31 August 2018.

Acknowledgements. The authors are grateful to Andrey A. Lukashov, Olga S. Shilova and numerous MSU students for fieldwork assistance and data processing during the 2008 winter expedition and the 2015-2018 summer training courses of the Geomorphology and Paleogeography Dept.

Financial support. This research has been supported by the Russian Foundation for Basic Research project no. 17-05-00630 in part of fieldwork organization and radiocarbon dating and by the Geomorphology and Paleogeography Dept., Faculty of Geography, MSU (Governmental Assignment of no. AAAA-A1611632810089-5) for assisting with grain size and radioisotope measurements.

\section{References}

Ananiev, G. S.: Catastrophic processes of land formation, MSU Publ, Moscow, Russia, 1998 (in Russian).

André, M. F.: Holocene Climate Fluctuations and Geomorphic Impact of Extreme Events in Svalbard, Geogr. Ann. A, 77, 241-250, 1995.

Belyaev, Y. R., Bredikhin, A. V., and Lukashov A. A.: Environmental geomorphologic safety of planning technical roads in the Khibiny Mountains, Georisk, 2, 50-57, 2015 (in Russian).

Bozhinsky, A. N. and Myagkov, S. M. (Eds.): Slushflows in Khibiny Mountains, MSU Publ., Moscow, Russia, 2001 (in Russian).

Chernous, P. A.: Destroying avalanche-like processes in the Khibiny Mountains: damage mitigation, in: Proceedings of the INTERPRAEVENT International Symposium Disaster Mitigation of Debris Flows, Slope Failures and Landslides, 25-27 September 2006, Niigata, Japan, 255-266, 2006.

Eckerstorfer, M. and Christiansen, H. H.: Meteorology, topography and snowpack conditions causing two extreme mid-winter slush and wet slab avalanche periods in high Arctic maritime Svalbard, Permafrost Periglac., 23, 15-25, 2012.

Fleishman, S. M.: Debris flows, Hydrometeoizdat, Leningrad, Russia, 1978 (in Russian).

Garankina, E. V.: Evolution of the cryogenic microrelief of the Subarctic low mountains, Earth's Cryosphere, 17, 3-16, 2013 (in Russian).

Garankina, E. V. and Lukashov, A. A.: Potential triggering role of seismic episodes for debris flow phenomena in the Khibiny (Kola Peninsula, Russia), Georisk, 12, 48-57, 2018 (in Russian).

Garankina, E. V., Belyaev, V. R., Belyaev, Y. R., Bondar, A. I., Gurinov, A. L., Ivanov, M. M., Romanenko, F. A., Rudinskaya, A. I., Shishkina, Y. V., and Tulyakov, E. D.: Slushflows as a land sculpturing agent in mountain valleys of the Kola Peninsula, Northwestern Russia, in: Practical Geography and XXI Century Challenges. IGU Thematic Conference, 4-6 June 2018, Moscow, Russia, Conf. Book. Part 1, 52-59, 2018.

Gorbatov, E. S. and Kolesnikov, S. F.: Deformation Structures in Glaciolacustrine Deposits of Khibiny and Assessment of Their Seismogenic Potential, Seismic Instruments, 53, 224-233, 2017.

Hestnes, E.: Slushflow hazard - where, why and when? 25 years of experience with slushflow consulting and research, Ann. Glaciol., 26, 370-376, 1998.

Hestnes, E. and Kristensen, K.: The diversities of large slushflows illustrated by selected cases, in: Proceedings of the International Snow Science Workshop, 17-22 October 2010, Squaw Valley, CA, USA, 348-355, 2010.

Ivanov, M. M., Belyaev, V. R., Garankina, E. V., Gurinov, A. L., Dobrydneva, L. V., Kuzmenkova, N. V., Romanenko, F. A., and Tulyakov, E. D.: Application of ${ }^{232}$ Th Daughter Radionuclides for Studying Exogenic Processes, Izvestiya of Russian Academy of Sciences, Geography Series, 6, 81-92, 2018 (in Russian).

Ivanov, M. M., Kuzmenkova, N. V., Garankina, E. V., and Tulyakov, E. D.: The ${ }^{232} \mathrm{Th}$ distribution in modern sediments near radioactive lovchorrite mine, the Khibiny Mountains, Kola Peninsula, J. Geochem. Explor., 200, 77-83, https://doi.org/10.1016/j.gexplo.2019.01.005, 2019.

Jonsson, A. and Gauer, P.: Optimizing mitigation measures against slush flows by means of numerical modelling a case study Longyearbyen, Svalbard, in: Proceedings of INTERPRAEVENT-2014 in the Pacific Rim - Natural Disaster Mitigation to Establish Society with the Resilience, 25-28 November 2014, Nara, Japan, 224-225, 2014.

Kobayashi, S., Izumi, K., and Kamiishi, I.: Slushflow disasters in Japan and its characteristics, International Snow Science Workshop, 30 October-3 November 1994, Snowbird, Utah, USA, 657-665, 1994.

Kosareva, Y. M.: Soils evolution in high mountains of Khibiny in Holocene, PhD Thesis, Moscow, Russia, 2007 (in Russian).

Larocque, S. J., Hetu, B., and Filion, L.: Geomorphic and Dendroecological impacts of slushflows in Central Gaspe Peninsula (Quebec, Canada), Geogr. Ann. A, 83, 191-201, 2001.

Nikolaeva, S. B.: Fold deformations in the Late Pleistocene deposits of Khibiny (the central part of the Kola Peninsula): morphology and genesis, Vestnik of Moscow State Technical University, 17, 329-339, 2014 (in Russian).

Nikolaeva, S. B., Lavrova, N. B., Denisov, D. B., and Tolstobrov, D. S.: Traces of catastrophic processes in bottom sediments of lakes on the western coast of Lake Babinskaya Imandra, Izvestiya of Russian Geographic Society, 148, 38-52, 2016 (in Russian).

Nyberg, R.: Observation of slushflows and their geomorphical effects in the Swedish mountain area, Geogr. Ann., A, 71, 185198, 1989.

Perov, V. F.: Debris flows in Khibiny mountain massif, Vestn. Mosk. U., Seriya 5 Geographicheskaya, 1, 106-110, 1966 (in Russian).

Perov, V. F.: Attempt to use dendrochronological method for studying frequency of debris flows at Khibiny, in: Fitoindikatsionnyye metody v glyatsiologii, MSU Publ., Moscow, Russia, 4249, 1971 (in Russian).

Perov, V. F.: Debris flow phenomena: terminological dictionary, MSU Pupbl., Moscow, Russia, 1996 (in Russian). 
Perov, V. F., Chernomorets, S., Budarina, O., Savernyuk, E., and Leontyeva, T.: Debris flow hazards for mountain regions of Russia: regional features and key events, Nat. Hazards, 88, 199-235, https://doi.org/10.1007/s11069-017-2841-3, 2017.

Pozhilenko, V. I., Gavrilenko, B. V., Zhirov, B. B., and Zhabin, S. V.: Geology of ore zones of Murmansk region, KNC RAS Publ., Apatity, Russia, 2002 (in Russian).

Relf, G., Kendra, J., Schwartz, R., Leathers, D., and Levia, D.: Slushflows: science and planning considerations for an expanding hazard, Nat. Hazards, 78, 333-354, https://doi.org/10.1007/s11069-015-1716-8, 2015.

Romanenko, F. A., Lukashov, A. A., and Shilova, O. S.: Catastrophic gravitational processes at the North of European Russia and an attempt of their absolute age dating, Geomorfologiya, 1, 87-94, 2011 (in Russian).

Rudinskaya, A. I., Belyaev, Y. R., Gurinov, A. L., and Garankina, E. V.: Debris flow phenomena in the Lovozerskiye Tundry, in: Debris Flows: Disasters, Risk, Forecast, Protection, Proceedings of the 5th International Conference, 1-5 October 2018, Tbilisi, Georgia, 529-537, 2018 (in Russian).

Sapunov, V. N.: Slushflows in Khibiny, Materialy gljaciologicheskih issledovanij, 71, 94-99, 1991 (in Russian).
Shilova, O. S. and Romanenko, F. A.: Tracking of Holocene evolutionary and catastrophic processes in lake sediments of Schuchje Lake (Khibiny, Kola Peninsula), in: Proceedings of the AllRussian Scientific Conference, dedicated to the memory of Professor A. A. Velichko, 23-25 November 2016, Moscow, Russia, 1, 381-385, 2016 (in Russian).

Sulerzhitskiy, L. D., Ryabinin, A. O., Zaychuk G. I., and Vinogradova, S. N.: Radiocarbon dates of Geological Institute Laboratory of the AS USSR, Byulleten komissii po izucheniyu chetvertichnogo perioda, 5, 145-153, 1986 (in Russian).

Vashchalova, Ò. V.: Paleogeographic approach to reconstruct snow avalanche activity for long-term forecasting by example of Khibiny, in: Assessment and long-term forecast of environmental changes of mountains, MSU Publ., Moscow, Russia, 120-128, 1987 (in Russian).

Vladychensky, A. C., Kovaleva, N. O., Kosareva, Y. M., and Ivanov, V. V.: Soils Mineralogy and Bulk Composition in Trough Valleys of Khibiny Mountain Range, Doklady po ekologicheskomu pochvovedeniyu, 1, 1-19, 2007 (in Russian). 